\title{
Variasi Ketebalan Kemasan Plastik Polypropylen Pada Pengemasan Vakum Buah Melon (Cucumis Melo L) Terolah Minimal
}

(Variation The Thickness Variation Polypropylen In Plastic Packaging Vacuum Packaging Fruit Melon (Cucumis Melo L) treated Minimal)

\author{
Erin Karlina ${ }^{1}$, Ratna ${ }^{2}$ Zulfahrizal $^{\mathbf{3}}$ \\ Program Studi Teknik Pertanian, Fakultas Pertanian, \\ Universitas Syiah Kuala
}

\begin{abstract}
Abstrak. Penelitian ini bertujuan untuk melihat pengaruh variasi ketebalan kemasan plastik polypropylen pada pengemasan vakum buah melon (Cucumis melo L) terolah minimal selama penyimpanan dengan menggunakan beberapa variasi ketebalan kemasan plastik polypropylen $0,03 \mathrm{~mm}$, $0,05 \mathrm{~mm}, 0,08 \mathrm{~mm}$ dan $0,09 \mathrm{~mm}$ pada suhu $10^{\circ} \mathrm{C}$. Pengambilan data dilakukan sebanyak 3 kali ulangan dengan analisis data 2 hari sekali hingga penelis menolak. Analisis mutu buah melon terolah minimal selama penyimpanan dilakukan terhadap susut bobot, kekerasan, total padatan terlarut, vitamin $\mathrm{C}$ dan uji organoleptik yang meliputi warna, aroma, rasa, tekstur dan penerimaan keseluruhan.
\end{abstract}

Kata kunci : Pengemasan Vakum, buah melon, kemasan plastik polypropylen.

\begin{abstract}
This study aims to look at the effect of variations in the thickness of the plastic packaging vacuum packaging polypropylen on melon (Cucumis melo L) minimally processed during storage by using some variation of the thickness of the plastic packaging polypropylen $0.03 \mathrm{~mm}, 0.05 \mathrm{~mm}, 0.08$ $\mathrm{mm}$ and $0,09 \mathrm{~mm}$ at a temperature of $100 \mathrm{C}$. Data is collected as much as 3 repetitions with the data analysis 2 days until panelist refused. Analysis of the quality of minimally processed melon fruit during storage is done on weight loss, hardness, total dissolved solids, vitamin $\mathrm{C}$ and organoleptic tests that include color, aroma, flavor, texture and overall acceptance.
\end{abstract}

Keywords: Vacuum packaging, melon, plastic packaging polypropylen.

\section{PENDAHULUAN}

Melon (Cucumis melo L) merupakan salah satu jenis buah yang banyak digemari oleh masyarakat, melon adalah buah-buahan yang mudah untuk dikembangkan. juga kaya akan vitamin A dan vitamin $\mathrm{C}$, rendah kalori, tidak mengandung lemak maupun kolestrol sehingga baik untuk dikonsumsi sehari-hari. Melon digunakan sebagai buah terolah minimal untuk dapat menjadikan buah melon untuk praktis dan mudah dikonsumsi. Buah terolah minimal perlu dilakukan untuk dapat menghilangkan bagian-bagian yang tidak bisa dimakan serta melakukan pengecilan ukuran (pemotongan/pengirisan) sehingga mempercepat penyajian. Kelebihan buah terolah minimal selain memudahkan dalam penyajian juga dapat memungkinkan konsumen melihat secara langsung kondisi bagian dalam produk sehingga menawarkan mutu yang lebih terjamin dibandingkan buah utuh. Bahkan konsumen dapat membeli beberapa jenis potongan buah dalam satu kemasan dengan ukuran berat yang relatif kecil, sehingga bisa memenuhi selera sekaligus menghemat pengeluaran (Fisla, 2010).

Pengemasan vakum pada buah terolah minimal dilakukan agar umur simpan buah terolah minimal lebih lama di dalam kemasan plastik. Pengemasan vakum menggunakan plastik memiliki tingkat permeabilitas terhadap $\mathrm{O}_{2}$ dan $\mathrm{CO}_{2}$ tertentu sehingga menghasilkan konsentrasi gas $\left(\mathrm{O}_{2}\right.$ dan $\left.\mathrm{CO}_{2}\right)$ di dalam kemasan yang optimum sesuai yang direkomendasikan untuk produk yang dikemas (Mandana et al., 2013).

Penyimpanan dalam suhu dingin merupakan salah satu cara untuk mengawetkan buah. Rasa/bau, warna, bentuk, tekstur dan nutrisi buah biasanya masih seperti semula bila disimpan 
dalam suhu dingin, tidak sebagaimana dengan cara penyimpanan lainnya. Penyimpanan pada suhu dingin tidak dapat meningkatkan kualitas produk akan tetapi dapat menghambat proses kerusakan dan mempertahankan umur simpannya. Oleh karenanya, buah yang akan disimpan dalam suhu dingin harus dipanen pada saat kondisi tingkat ketuaan yang sama (Ashari, 2006).

\section{METODE PENELITIAN}

Penelitian ini dilaksanakan pada bulan Mei sampai Juli 2016 di Laboratorium Pasca Panen, Program Studi Teknik Pertanian, Fakultas Pertanian, Universitas Syiah Kuala, Darussalam, Kota Banda Aceh.

\section{Alat dan Bahan}

Alat-alat yang digunakan pada penelitian ini adalah timbangan digital dalam skala 1000 gram, vakum sealer model powerpack DZ300T/A dengan besarnya tekanan 0,06 Mpa, pisau, kulkas, hardness tester, dan refraktometer.

Bahan-bahan yang digunakan dalam penelitian ini adalah buah melon yang berasal dari kebun BPTP Lampineung, Kota Banda Aceh dan menggunakan variasi ketebalan kemasan plastik Polypropylen 0,03 $\mathrm{mm}, 0,05 \mathrm{~mm}, 0,08 \mathrm{~mm}$ dan 0,09 $\mathrm{mm}$.

\section{Metode Penelitian}

Penelitian ini menggunakan buah melon yang dipanen langsung dari kebunnya. Tahap pertama yang dilakukan pada buah melon adalah membersihkan buah melon dan lalu dipotong dengan arah memanjang dengan tebal $3 \mathrm{~cm}$, lebar $2 \mathrm{~cm}$. Selanjutnya buah melon yang sudah terolah minimal lalu ditimbang untuk mendapatkan berat awal. Setelah itu buah dimasukkan ke dalam plastik polypropylen dengan variasi ketebalan. Sebagian potongan buah melon dijadikan sebagai penyimpanan pada suhu kontrol. Kemudian kemasan divakumkan dengan vakum sealer, dengan tekanan 0,06 mpa dan di simpan pada suhu $10^{\circ} \mathrm{C}$.

\section{Prosedur Pengujian di Laboratorium}

\section{Susut Bobot}

(Sudarmadji et al., 1984). Nilai susut bobot diperoleh dari persentase antara penurunan berat bahan awal hingga akhir penyimpanan. Digunakan persamaan sebagai berikut :

$\%$ Susut Bobot $=\frac{(\text { Bobot Awal }- \text { Bobot Akhir })}{\text { Bobot Awal }} \times 100 \%$

\section{Kekerasan}

(Sudarmadji et al., 1984). Kekerasan buah diukur dengan menggunakan Fruit Hardness Tester. Prinsip kerja alat ini adalah untuk menentukan besarnya tekanan yang diperlukan untuk dapat memasukkan alat penekan kedalam buah melon sampai batas tertentu.

$$
\sigma=\frac{\mathrm{P}}{\mathrm{A}}
$$

\section{Dimana :}

$\sigma=$ Tingkat kekerasan $\left(\mathrm{kg} / \mathrm{cm}^{2}\right)$

$\mathrm{P}=$ Gaya tekan dari hasil pembacaan alat $(\mathrm{kg})$

$\mathrm{A}=$ Luas alat penekan $\left(\mathrm{cm}^{2}\right)$ 
Alat penekan berbentuk kerucut terbalik dengan diameter $1,2 \mathrm{~cm}$, karena tapak berbentuk lingkaran maka rumus menjadi:

$\sigma=4 \mathrm{P} / \pi \mathrm{d}^{2}$

Keterangan: $\mathrm{d}=$ diameter lingkaran $(\mathrm{cm})$.

\section{Total Padatan Terlarut}

Alat yang digunakan untuk mengukur kadar atau konsentrasi bahan terlarut adalah Refraktometer digital dengan range 0-32 \% Brix. Sampel yang akan dianalisa diperas dan cairan yang diperoleh diteteskan pada prisma pengukur refraktometer. Total padatan terlarut dibaca dengan satuan \%Brix (Muhtadi, 1990).

\section{Vitamin C}

Perhitungan vitamin $\mathrm{C}$ dengan standarisasi larutan iodin yaitu pada setiap $1 \mathrm{ml} 0,01 \mathrm{~N}$ iodin ekuivalen dengan $0,88 \mathrm{mg}$ asam askorbat.

$$
\mathrm{A}=\frac{\mathrm{V} \times 0,88 \times \mathrm{P} \times 100}{\mathrm{~S}}
$$

Keterangan:

$\mathrm{A} \quad=$ Kadar vitamin $\mathrm{C}(\mathrm{mg} / 100$ gr bahan $)$

$\mathrm{V}=$ Jumlah iod $0,01 \mathrm{~N}$ untuk titrasi $(\mathrm{ml})$

$\mathrm{P} \quad=$ Faktor pengencer.

$0,08=$ Milligram asam askrobat untuk $1 \mathrm{ml}$ iod $0.01 \mathrm{~N}$

$\mathrm{S} \quad=$ Berat Sampel

\section{Uji Organoleptik}

Pengujian organoleptik dilakukan terhadap penampakan secara umum terdiri dari warna, rasa, aroma, tekstur pada daging buah melon dan penerimaan keseluruhan. Penilaian terhadap nilai kesukaan dilakukan oleh 25 orang panelis yang dianggap mewakili konsumen. Dengan skala hedonik, 1=Sangat tidak suka, 2= Tidak suka, 3=Netral, 4= suka, dan 5= Sangat Suka (Soekarto, 1990).

\section{HASIL DAN PEMBAHASAN}

Hasil penelitian pendahuluan umur simpan buah melon terolah minimal ada tiga perlakuan yaitu:

1. Melon terolah minimal yang dikemas biasa pada suhu ruang hanya dapat bertahan selama 3 hari penyimpanan, setelah itu buah melon terolah minimal terlihat dari segi warna sudah pudar dan berbau aroma membusuk.

2. Melon terolah minimal tanpa kemasan di simpan pada suhu dingin hanya dapat bertahan selama 2 hari penyimpanan, setelah itu permukaan daging buah melon terlihat berair dan berbau aroma membusuk.

3. Melon terolah minimal tanpa kemasan di simpan pada suhu ruang hanya bertahan selama 1 hari penyimpanan, setelah itu warna pada daging buah melon sudah terlihat menghitam, tekstur pada daging buah melon menjadi lembek dan berbau aroma membusuk.

Berdasarkan hasil penelitian pendahuluan umur simpan buah melon terolah minimal dengan 3 perlakuan yang berbeda-beda mendapatkan umur simpan yang sangat singkat 1-3 hari penyimpanan, dibandingkan dengan umur simpan buah melon terolah minimal yang dikemas 
dengan variasi ketebalan kemasan plastik polypropylen dan dilakukan pengemasan vakum dengan tekanan 0,06 Mpa dapat bertahan selama 10 hari penyimpanan.

\section{Susut Bobot}

Hasil penelitian terhadap susut bobot buah melon untuk semua variasi ketebalan kemasan plastik polypropylen pada suhu penyimpanan $10^{\circ} \mathrm{C}$ hanya dapat bertahan sampai hari ke-10, dan nilai susut bobot semakin meningkat untuk semua variasi ketebalan kemasan plastik polypropylen dengan perlakuan yang berbeda-beda seperti terlihat pada Gambar 3 .

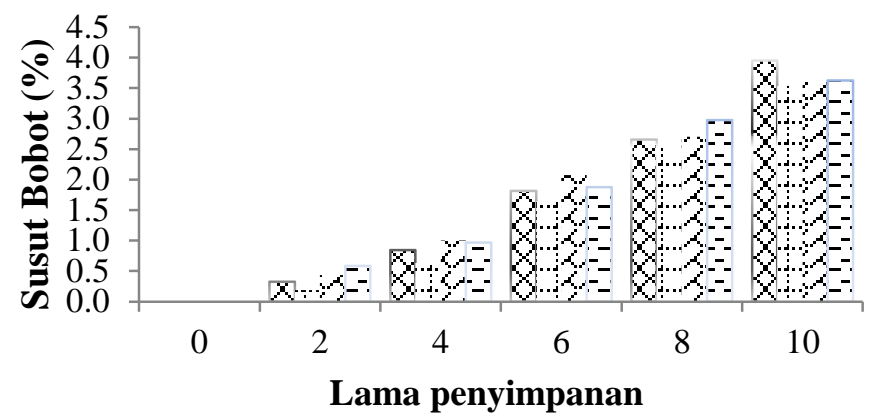

Keterangan:

$\varangle \mathrm{K} 1=$ Kemasan plastik polypropylen dengan ketebalan $0,03 \mathrm{~mm}$

$\mathrm{K} 2=$ Kemasan plastik polypropylen dengan ketebalan $0,05 \mathrm{~mm}$

$\therefore \mathrm{K} 3=$ Kemasan plastik polypropylen dengan ketebalan $0,08 \mathrm{~mm}$

$\mathrm{K} 4=$ Kemasan plastik polypropylen dengan ketebalan $0,09 \mathrm{~mm}$

Gambar 3. Hubungan Susut Bobot Buah Melon untuk Variasi Ketebalan Kemasan Plastik Polypropylen dan Suhu Selama Penyimpanan.

Berdasarkan hasil analisis sidik ragam pengemasan vakum dengan tekanan 0,06 Mpa pada buah melon terolah minimal didapat nilai signifikan sebesar 0,985 , dari nilai tersebut perlakuan variasi ketebalan kemasan plastik polypropylen tidak berpengaruh nyata terhadap susut bobot selama penyimpanan, maka tidak dilanjutkan dengan pengujian uji lanjut Duncan terhadap signifikan 5\%.

\section{Kekerasan}

Hasil penelitian menunjukkan bahwa kekerasan buah melon terolah minimal untuk variasi ketebalan kemasan plastik polypropylen dan suhu penyimpanan $10^{\circ} \mathrm{C}$ berkisar antara $1,36-0,38 \mathrm{~kg} / \mathrm{cm}^{2}$, seperti yang terlihat pada Gambar 4. Nilai kekerasan buah melon terolah minimal pada hari ke-0 penyimpanan adalah $1,36 \mathrm{~kg} / \mathrm{cm}^{2}$.

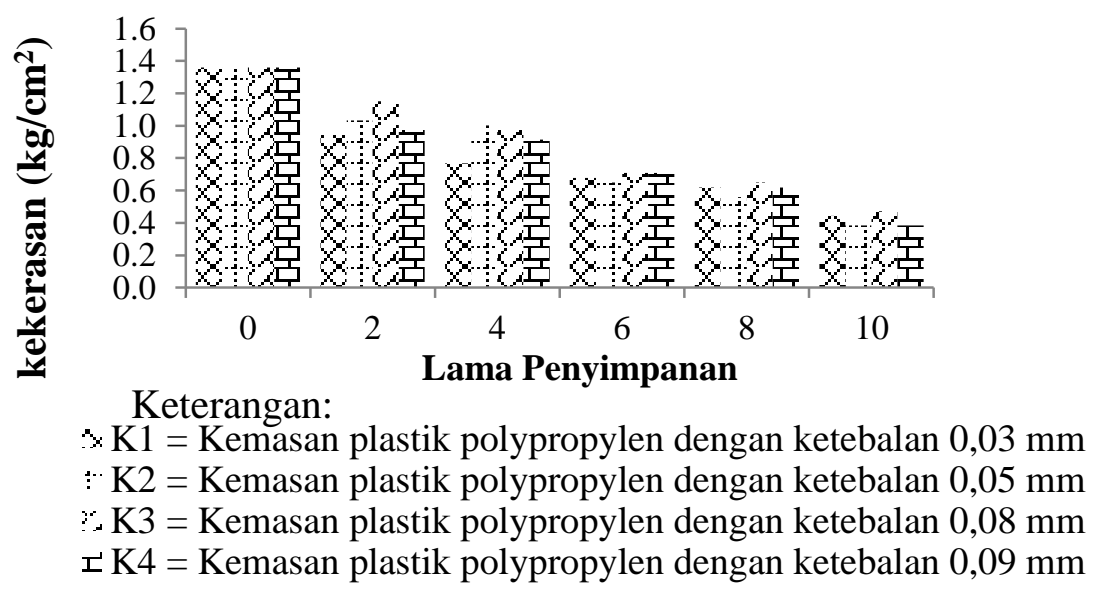


Gambar 4. Hubungan Kekerasan Buah Melon untuk Semua Variasi Ketebalan Kemasan Plastik Polypropylen dan Suhu Selama Penyimpanan.

Nilai kekerasan menunjukkan tingkat kesegaran pada buah melon terolah minimal, namun nilai kekerasan dikatakan baik, tidak hanya dikarenakan nilai kekerasannya yang terlalu tinggi atau rendah saja, melainkan tergantung dari kondisi fisik buah melon tersebut (Santoso dan Rahmi, 2011 dalam Dewi, 2015).

Berdasarkan hasil analisis sidik ragam menunjukkan bahwa pengemasan vakum dengan tekanan 0,06 Mpa didapat nilai signifikan sebesar 0,678, dari nilai tersebut perlakuan variasi ketebalan kemasan plastik polypropylen tidak berpengaruh nyata terhadap kekerasan buah melon terolah minimal selama penyimpanan, maka tidak dilanjutkan dengan pengujian uji lanjut Duncan terhadap signifikan 5\%

\section{Total Padatan terlarut}

Hasil penelitian terhadap total padatan terlarut buah melon untuk semua variasi ketebalan kemasan plastik polypropylen pada penyimpana suhu $10^{\circ} \mathrm{C}$ dapat dilihat pada Gambar 5.

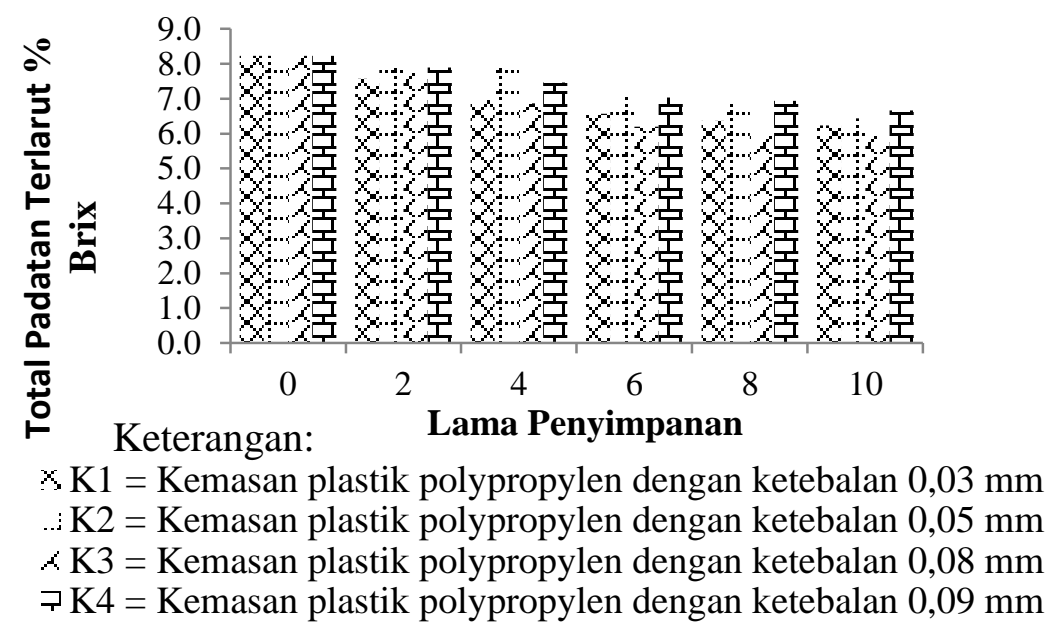

Gambar 5. Hubungan Total Padatan Terlarut Buah Melon untuk Semua Variasi Ketebalan Kemasan Plastik Polypropylen dan Suhu Selama Penyimpanan.

Pengukuran total padatan terlarut ditetapkan dalam satuan Brix yaitu zat padat kering terlarut dalam suatu larutan yang dihitung sebagai sukrosa (gula). Kualitas buah melon juga ditentukan oleh kandungan kadar gula sebagai total padatan terlarut, hal ini disebabkan karena buah melon setelah dilakukan pemanenan dan masa penyimpanan nya masih mengalami perubahan fisiologi hingga memasuki masa kelayuan (Hayati, 2015).

Berdasarkan hasil analisis sidik ragam menunjukkan bahwa pengemasan vakum dengan tekanan 0,06 Mpa didapat nilai signifikan sebesar 0,337, dari nilai tersebut perlakuan variasi ketebalan kemasan plastik polypropylen tidak berpengaruh nyata terhadap kandungan total padatan terlarut buah melon terolah minimal selama penyimpanan, maka tidak dilanjutkan dengan pengujian uji lanjut Duncan terhadap signifikan 5\%.

\section{Vitamin C}

Kandungan vitamin $\mathrm{C}$ buah melon terolah minimal selama penyimpanan dengan penyimpanan suhu $10^{\circ} \mathrm{C}$ yang dikemas dengan pengemasan vakum pada variasi ketebalan 
kemasan plastik polypropylen, semakin lama waktu penyimpanannya makaakan semakin menurun kandungan vitamin $\mathrm{C}$ untuk semua perlakuan.

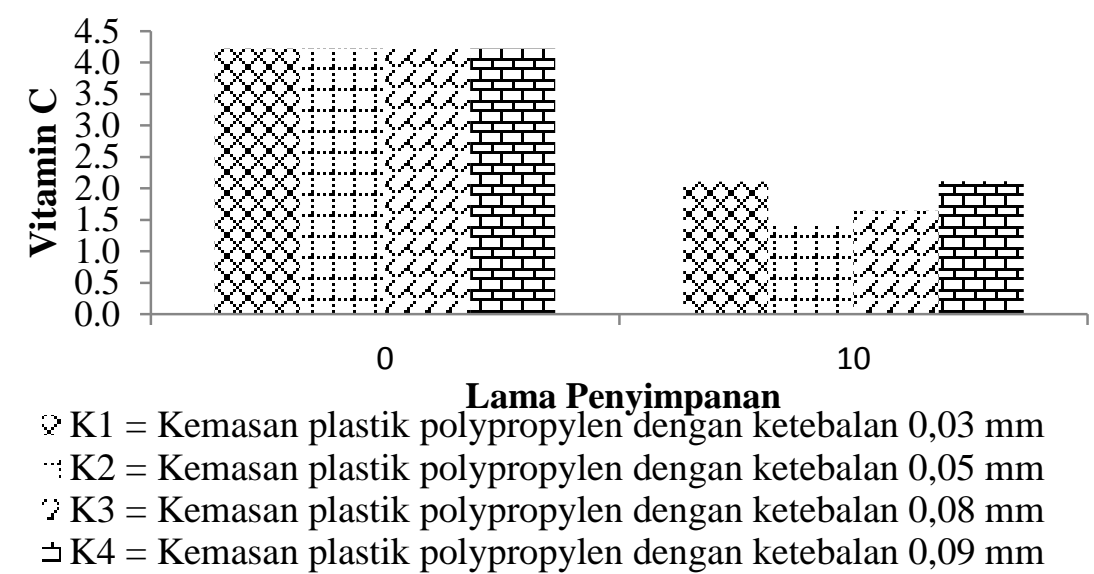

Gambar 6. Hubungan Vitamin C Buah Melon untuk Semua Variasi Ketebalan Kemasan Plastik Polypropylen dan Suhu Selama Penyimpanan.

Penurunanan kandungan vitamin $\mathrm{C}$ selama penyimpanan disebabkan karna sifat vitamin $\mathrm{C}$ yang mudah larut dalam air sehingga sangat mudah hilang akibat bekas pengirisan/pemotongan.

Berdasarkan hasil analisis sidik ragam menunjukkan bahwa pengemasan vakum dengan tekanan 0,06 Mpa didapat nilai signifikan sebesar 0,520, dari nilai tersebut perlakuan variasi ketebalan kemasan plastik polypropylen tidak berpengaruh nyata terhadap kandungan vitamin $\mathrm{C}$ buah melon terolah minimal selama penyimpanan, maka tidak dilanjutkan dengan pengujian uji lanjut Duncan terhadap signifikan 5\%.

\section{Uji Organoleptik}

. Uji organoleptik diterapkan untuk mengetahui respon dari konsumen yang tidak terlatih atau lebih dikenal dengan penerimaan panelis terhadap suatu produk. Jumlah panelis yang digunakan pada penyimpanan buah melon terolah minimal ini sebanyak 25 orang penelis dan pengambilan data uji organoleptik dilakukan pada hari ke-0, ke-2, ke-4, ke-6, ke-8 dan ke-10.

\section{Uji Organoleptik Warna}
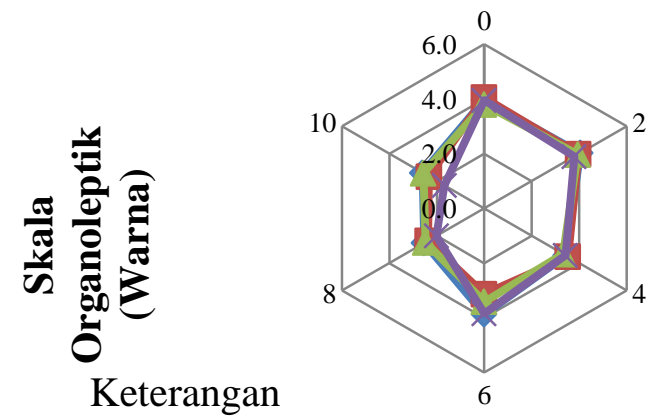

Keterangan

$\sim \mathrm{K} 1=$ Kemasan plastik polypropylen dengan ketebalan 0,03 $\mathrm{mm}$

$-\mathrm{K} 2=$ Kemasan plastik polypropylen dengan ketebalan 0,05 $\mathrm{mm}$

$-\mathrm{K} 3=$ Kemasan plastik polypropylen dengan ketebalan 0,08 $\mathrm{mm}$

$* \mathrm{~K} 4=$ Kemasan plastik polypropylen dengan ketebalan 0,09 mm 
Gambar 7. Nilai Uji Organoleptik Warna Pada Variasi Ketebalan Kemasan Plastik Polypropylen dan Suhu Penyimpanan Terhadap Warna Buah Melon Terolah Minimal Selama Penyimpanan.

Suatu bahan makanan yang bernilai gizi tinggi, enak dan teksturnya baik tidak akan dimakan apabila memiliki warna yang tidak menarik. Warna membuat makanan terlihat menarik dan merupakan daya tarik utama sebelum panelis mengenal dan menyukai sifat-sifat lainnya (Hayati, 2015).

Berdasarkan hasil analisis sidik ragam menunjukkan bahwa pengemasan vakum dengan tekanan 0,06 Mpa didapat nilai signifikan sebesar 0,045, dari nilai tersebut perlakuan variasi ketebalan kemasan plastik polypropylen berpengaruh nyata terhadap uji organoleptik warna, maka dilanjutkan dengan uji lanjut Duncan terhadap signifikan 5\%.

Hasil uji lanjut Duncan berdasarkan nilai signifikan 5\% kemasan plastik polypropylen ketebalan 0,03 mm (K1), 0,05 mm (K2) dan 0,08 mm (K3) mendapatkan nilai lebih tertinggi di bandingkan dengan kemasan plastik polypropylen ketebalan 0,09 $\mathrm{mm}(\mathrm{K} 4)$. Maka berpengaruh nyata terhadap uji organoleptik untuk warna pada buah melon terolah minimal selama penyimpanan.

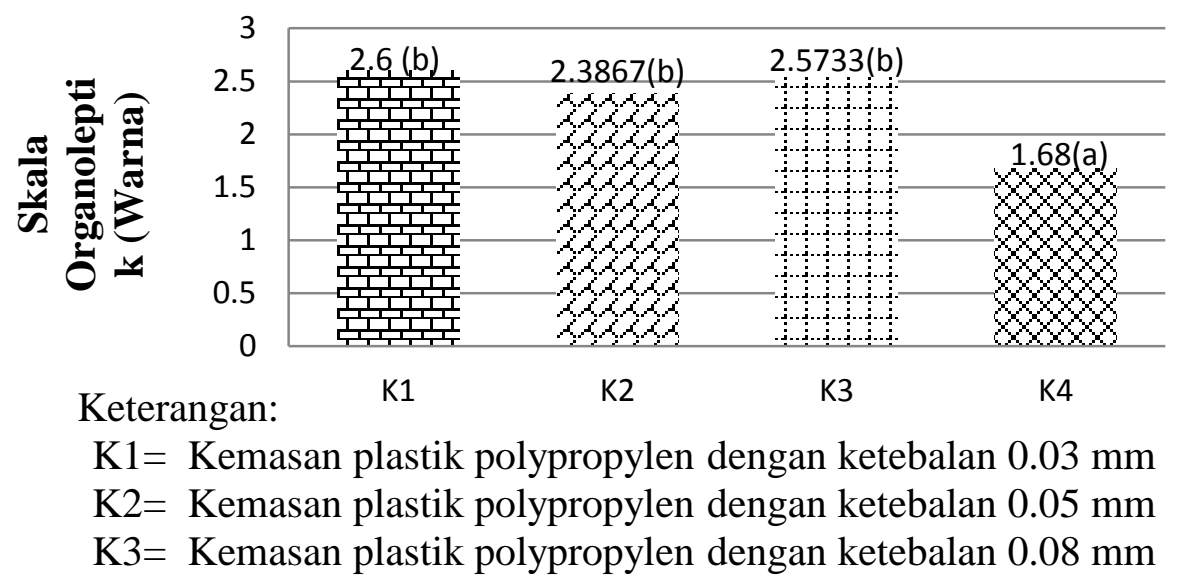

Gambar 8. Uji lanjut Duncan 5\% Terhadap Uji Organoleptik Warna Buah Melon Terolah Minimal Selama Penyimpanan.

\section{Uji organoleptik Aroma}




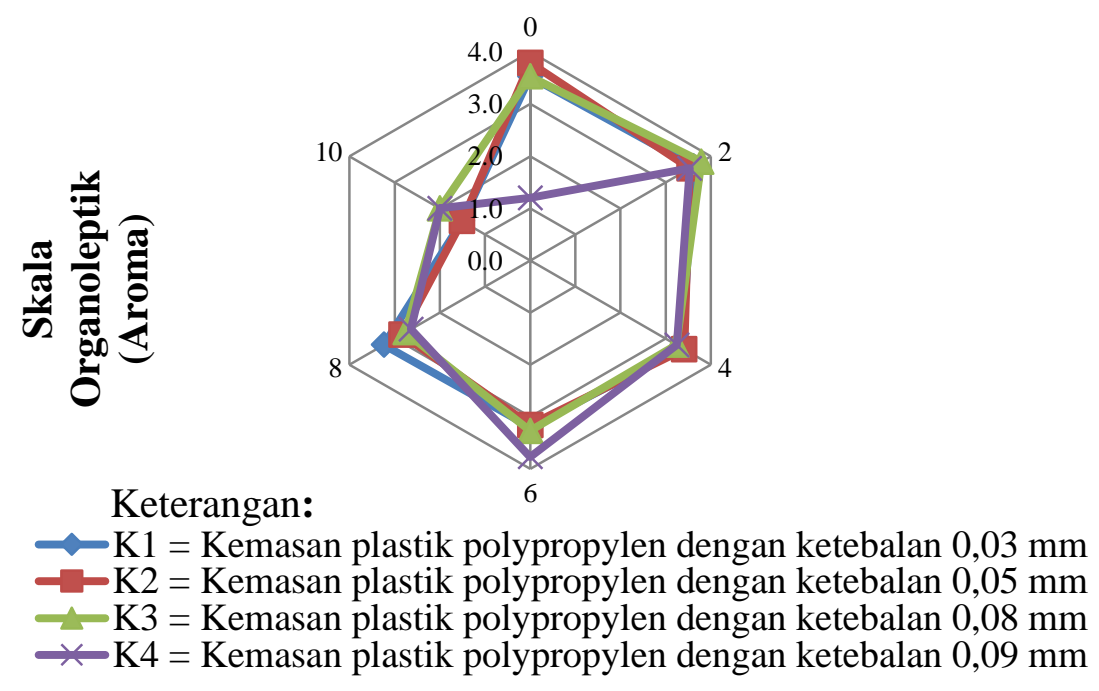

Gambar 9. Nilai Uji Organoleptik Aroma Pada Variasi Ketebalan Kemasan Plastik Polypropylen dan Suhu Penyimpanan Terhadap Aroma Buah Melon Terolah Minimal Selama Penyimpanan.

Aroma merupakan salah satu faktor penting bagi konsumen dalam memilih produk makanan yang disukai. Berdasarkan hasil analisis sidik ragam menunjukkan bahwa pengemasan vakum dengan tekanan $0,06 \mathrm{Mpa}$ didapat nilai signifikan sebesar 0,158 , dari nilai tersebut perlakuan variasi ketebalan kemasan plastik polypropylen tidak berpengaruh nyata terhadap uji organoleptik aroma buah melon terolah minimal selama penyimpanan, maka tidak dilanjutkan dengan pengujian uji lanjut Duncan terhadap signifikan 5\%.

\section{Uji Organoleptik Rasa}
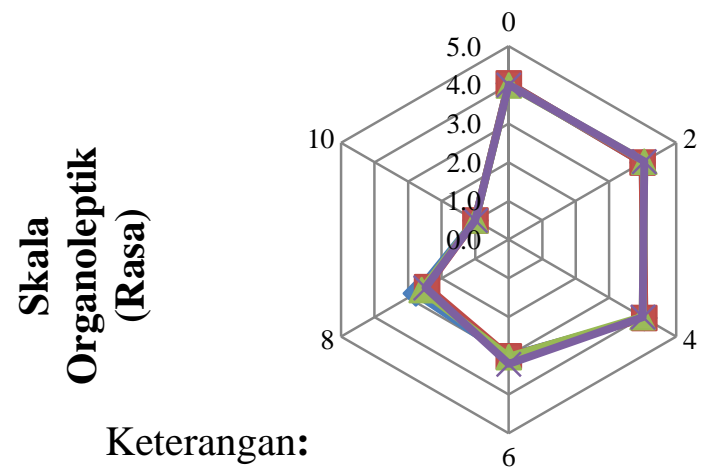

\section{Keterangan:}

$\neg \mathrm{K} 1=$ Kemasan plastik polypropylen dengan ketebalan $0,03 \mathrm{~mm}$

$-\mathrm{K} 2=$ Kemasan plastik polypropylen dengan ketebalan $0,05 \mathrm{~mm}$

$-\mathrm{K} 3=$ Kemasan plastik polypropylen dengan ketebalan 0,08 $\mathrm{mm}$

$* \mathrm{~K} 4=$ Kemasan plastik polypropylen dengan ketebalan 0,09 $\mathrm{mm}$

Gambar 10. Nilai Uji Organoleptik Rasa Pada Variasi Ketebalan Kemasan Plastik Polypropylen dan Suhu Penyimpanan Terhadap Rasa Buah Melon Terolah Minimal Selama Penyimpanan.

Berdasarkan hasil analisis sidik ragam menunjukkan bahwa pengemasan vakum dengan tekanan 0,06 Mpa didapat nilai signifikan sebesar 0,900, dari nilai tersebut perlakuan variasi ketebalan kemasan plastik polypropylen tidak berpengaruh nyata terhadap uji organoleptik rasa buah melon terolah minimal selama penyimpanan, maka tidak dilanjutkan dengan pengujian uji lanjut Duncan terhadap signifikan 5\%. 


\section{Uji Organoleptik Tekstur}

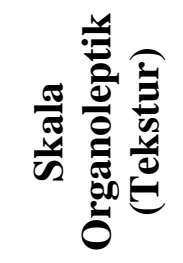

Keterangan

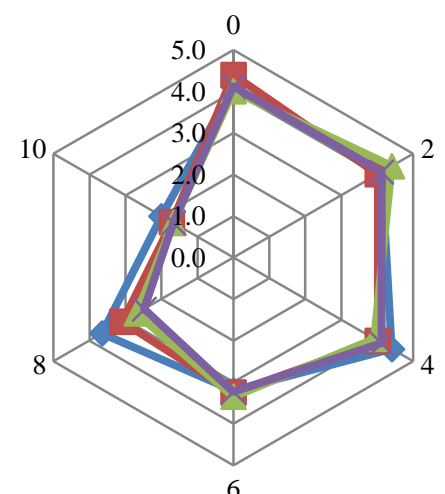

$\rightarrow \mathrm{K} 1=$ Kemasan plastik polypropylen dengan ketebalan 0,03 mm

$-\mathrm{K} 2=$ Kemasan plastik polypropylen dengan ketebalan 0,05 $\mathrm{mm}$

$-\mathrm{K} 3=$ Kemasan plastik polypropylen dengan ketebalan 0,08 mm

$\leftarrow \mathrm{K} 4=$ Kemasan plastik polypropylen dengan ketebalan 0,09 mm

Gambar 11. Nilai Uji Organoleptik Tekstur Pada Variasi Ketebalan Kemasan Plastik Polypropylen dan Suhu Penyimpanan Terhadap Tekstur Buah Melon Terolah Minimal Selama Penyimpanan.

Berdasarkan hasil analisis sidik ragam menunjukkan bahwa pengemasan vakum dengan tekanan 0,06 Mpa didapat nilai signifikan sebesar 0,408, dari nilai tersebut perlakuan variasi ketebalan kemasan plastik polypropylen tidak berpengaruh nyata terhadap uji organoleptik tekstur buah melon terolah minimal selama penyimpanan, maka tidak dilanjutkan dengan pengujian uji lanjut Duncan terhadap signifikan 5\%.

\section{Uji Organoleptik Penerimaan Keseluruhan}

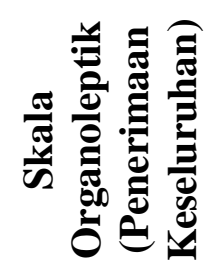

\section{Keterangan:}

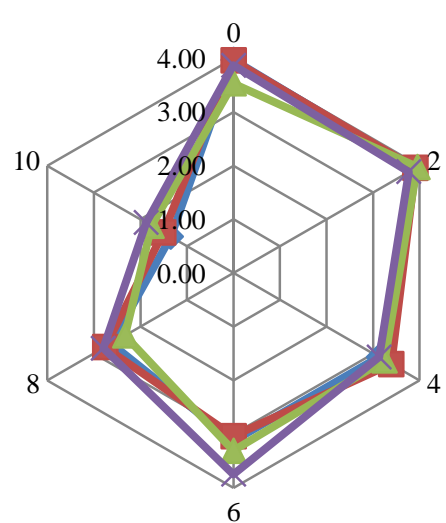

$\leadsto \mathrm{K} 1=$ Kemasan plastik polypropylen dengan ketebalan $0,03 \mathrm{~mm}$

$-\mathrm{K} 2=$ Kemasan plastik polypropylen dengan ketebalan $0,05 \mathrm{~mm}$

$-\mathrm{K} 3=$ Kemasan plastik polypropylen dengan ketebalan 0,08 mm

*K4 = Kemasan plastik polypropylen dengan ketebalan 0,09 mm

Gambar 12. Nilai Uji Organoleptik Penerimaan Keseluruhan Pada Variasi Ketebalan Kemasan

Plastik Polypropylen dan Suhu Penyimpanan. Terhadap Penerimaan Keseluruhan Buah Melon Terolah Minimal Selama Penyimpanan.

Berdasarkan hasil analisis sidik ragam menunjukkan bahwa pengemasan vakum dengan tekanan 0,06 Mpa didapat nilai signifikan sebesar 0,364, dari nilai tersebut perlakuan variasi 
ketebalan kemasan plastik polypropylen tidak berpengaruh nyata terhadap uji organoleptik penerimaan keseluruhan buah melon terolah minimal selama penyimpanan, maka tidak dilanjutkan dengan pengujian uji lanjut Duncan terhadap signifikan 5\%

\section{KESIMPULAN DAN SARAN}

Berdasarkan analisis sidik ragam bahwa variasi ketebalan kemasan plastik polypropylen tidak berpengaruh nyata terhadap parameter susut bobot, kekerasan, total padatan terlarut, vitamin $\mathrm{C}$ dan uji organoleptik aroma, rasa, tekstur, dan penerimaan keseluruhan, sedangkan variasi ketebalan kemasan plastik polypropylen berpengaruh nyata terhadap uji organoleptik untuk warna, maka dengan uji lanjut Duncan didapat kemasan plastik polypropylen ketebalan $0,03,0,05,0,08 \mathrm{~mm}$ lebih bagus dari kemasan plastik polypropylen ketebalan 0,09 $\mathrm{mm}$. Umur simpan buah melon terolah minimal pada suhu $10^{\circ} \mathrm{C}$ dapat bertahan sampai hari ke-10 penyimpanan, umur simpan ini lebih baik dibandingkan dengan umur simpan buah melon terolah minimal yang tidak mendapat perlakuan serupa.

\section{Saran}

Diharapkan pada penelitian selanjutnya perlu dilakukan penyimpanan buah melon terolah minimal ini dengan menggunakan variasi suhu refrigerator yang berbeda-beda selama penyimpanan.

\section{DAFTAR PUSTAKA}

Dewi, M.L. 2015. Umur simpan jamur tiram putih (Pleurotus ostreatus) dalam kemasan plastik polipropilen perforasi dengan variasi lubang dan suhu penyimpanan. Skripsi. Jurusan Teknik Pertanian, Fakultas Pertanian, Universitas Syiah Kuala, Banda Aceh.

Fisla, I.D. 2010. Pengaruh lapisan edible dan kemasan atmosfir termodifikasi terhadap umur simpan buah melon cantaloupe terolah minimal. Skripsi. Jurusan Teknik Pertanian, Fakultas Teknologi Pertanian, Institut Pertanian Bogor, Bogor.

Hastuti. 2012. Pengemasan bertekanan. http://dokumen.tips/documents/kemasan. html. Diakses tanggal 23 juli 2016.

Hayati, R. 2015. Analisis kualitas sauerkraut (Asinan Jerman) dari kol (Brassica Oleracea) selama fermentasi dengan variasi konsentrasi garam. Skripsi. Jurusan Teknik Pertanian, Fakultas Pertanian, Universitas Syiah Kuala, Banda Aceh.

Mandana, G.O., Utama, I. M. S., dan Yulianti, N. L. 2013. Pengaruh larutan desinfektan dan pengemasan atmosfer termodifikasi menggunakan film plastic terporasi terhadap susut bobot dan mutu buah cabai merah besar (Capsicum Annuum L) selama penyimpanan. Jurnal Teknologi Pertanian Volume 1, No 1. Jurusan Teknik Pertanian, Fakultas Teknologi Pertanian, Universitas Udayana.

Soekarto, T. 1990. Penilaian Organoleptik Untuk Industri Pangan dan Hasil Pertanian. Bhratara Karya Aksara, Jakarta. 